\title{
LATE CENOZOIC CHANGES IN ATMOSPHERIC CIRCULATION DEDUCED FROM NORTH PACIFIC EOLIAN SEDIMENTS
}

\author{
DAVID K. REA and THOMAS R. JANECEK \\ Oceanography Program, Department of Atmospheric and Oceanic Science, The University \\ of Michigan, Ann Arbor, MI 48109 (U.S.A.)
}

(Received December 23, 1981 ; revised and accepted March 18, 1982)

\begin{abstract}
Rea, D.K. and Janecek, T.R., 1982. Late Cenozoic changes in atmospheric circulation deduced from North Pacific eolian sediments. Mar. Geol., 49: 149-167.

Isolation and analysis of the eolian component of late Cenozoic pelagic sediments from the North Pacific provides direct information concerning changes in atmospheric circulation. A 50\% increase in intensity of both the prevailing westerlies and the tradewinds coincides with increasing pole-to-equator temperature gradients resulting from the onset of northern hemisphere glaciation. At the same time, the mass flux of dust from continents to the North Pacific increased by a factor of 4.5 , apparently reflecting significantly increased continental aridity associated with the late Cenozoic glacial ages.
\end{abstract}

\section{INTRODUCTION}

The intensity of atmospheric circulation through geologic time is an important parameter in our understanding of past climates and climatic change. Estimates of this parameter are generally indirect and rely upon the link between atmospheric and oceanic surface circulation (Van Andel et al., 1975; CLIMAP, 1976; Moore et al., 1980). Computer models of past atmospheric circulation depend upon the climatological information input (cf. Heath, 1979) and include wind intensities among their outputs (Gates, 1976; Menabe and Hahn, 1977), but eolian debris provides the only direct record of past-atmospheric circulation. We have been able to isolate that sedimentary component from pelagic sediments and quantify changes in the record of atmospheric circulation and eolian deposition at single sites spanning the Late Cretaceous (Rea and Janecek, 1981a), the entire Cenozoic (Janecek et al., 1980), and the past 450,000 yrs (Rea, 1982). Here we examine the eolian record at five locations in the North Pacific Ocean. Those cores span the last 7 to $10 \mathrm{~m} . \mathrm{y}$. and record the changes in the prevailing westerlies and the tradewinds that accompanied the onset of the late Cenozoic glacial ages. 


\section{Eolian sedimentation}

Eolian contributions to deep-sea sediments have been a topic of research for nearly twenty-five years (Rex and Golberg, 1958). Windom (1969) suggested that up to $75 \%$ of the non-biogenic component of North Pacific deep-sea sediment was atmospheric dust fallout, an estimate strengthened by Ferguson et al. (1970), who demonstrated the similarity between eolian dust mineralogy and that of deep North Pacific sediments. Wind-borne dusts have been sampled from ships and land-based stations (Delany et al., 1967; Prospero and Bonatti, 1969; Johnson, 1976; Windom and Chamberlain, 1978; Glaccum and Prospero, 1980; Prospero et al., 1981) and dust mineralogy compared to that of surface sediments (Lisitzin, 1972; Windom, 1975,1976 ; Johnson, 1979). Results of the various sampling programs indicate that dust is a significant component of pelagic sediments (Griffin et al., 1968). Away from the mouths of major rivers, patterns of sediment mineralogy (Windom, 1976) parallel the zonal wind regimes and so are roughly perpendicular to the boundary currents of the subtropical gyres. This observation serves to emphasize the rapid removal rate of small particles from the surface of the ocean (Berger, 1976). Up to 99\% of the vertical mass flux of particulate matter from the epipelagic and mesopelagic zones is accomplished by fecal pellet transport (Bishop et al., 1977, 1978). The process of ingestion of small grains by feeding zooplankton, incorporation of those grains into fecal pellets and the rapid settling of those pellets at hundreds of meters per day (Honjo and Roman, 1978; Honjo, 1980) quickly removes eolian dust (Scheidegger and Krissek, 1982) and all other particulates from the effects of ocean-surface circulation. Ocean-floor assemblages thus mimic sea-surface assemblages and surface-current related smearing of sedimentary patterns is minimal (Berger, 1976).

Samples recovered at distances greater than 1000 or $2000 \mathrm{~km}$ from land, seaward of the realm of hemipelagic deposition, and away from turbidites and ice-rafted debris contain eolian grains as their non-authigenic, inorganic component. Both air sampling (Johnson, 1976; Glaccum and Prospero, 1980) and theoretical calculations of dust transport (Windom, 1975; Schütz, 1979) have shown that beyond the $1000-2000 \mathrm{~km}$ distance from the source, the size distribution of the eolian grains remains constant; at the time of deposition the grains are in equilibrium with the strength of the transporting wind. Sediment samples coming to our laboratory commonly span about a 2 -cm length of core so at average pelagic sedimentation rates of $0.5-2.0 \mathrm{~cm} / 10^{3} \mathrm{yr}$ the samples present an integrated average of at least $1000-4000 \mathrm{yrs}$ of deposition and perhaps twice that amount depending upon bioturbation effects. The processes of pelagic deposition therefore act to filter higher frequency fluctuations out of the data and leave an integrated longer term signal for us to study.

Our data set is the mass accumulation rate (MAR) in $\mathrm{mg} / \mathrm{cm}^{2} / 10^{3} \mathrm{yr}$ and median grain size $\left(\phi_{50}\right.$ of Folk, 1974) of the total eolian component of deepsea sediments, not merely of quartz which commonly comprises less than 
20\% of the eolian load (Johnson, 1979; Glaccum and Prospero, 1980). The flux of wind-borne dust to the ocean basins depends in part on the strength of the zonal winds and on the distance from the source area but mostly upon the climate of the eolian source region (Rea and Janecek, 1981a). Humid climates promote vegetation, thereby reducing the amount of material available for wind erosion, transport and subsequent deposition in the deep-sea. High precipitation rates also increase scavenging of eolian dust by rain thus decreasing the amount of deposition downwind (Windom, 1975; Parkin and Padgham, 1975). Moist climates result in greater runoff and higher hemipelagic sedimentation rates, dry climates result in greater eolian MAR's - a relationship apparent in cores raised from the eastern equatorial Pacific (Rea, 1982).

In the simplest case, the intensity of the global wind systems should depend directly upon the pole-to equator temperature gradient. As this gradient becomes greater, the velocity of the zonal winds should increase. Changes in wind strength will result in a change in the size of the transported grains, with stronger winds carrying coarser grains. (Parkin, 1974; Rea, 1982). At distances less than $1000 \mathrm{~km}$ from the source, the size of eolian grains is almost certainly not in equilibrium with the winds as the larger grains are settling out rapidly (Johnson, 1976; Glaccum and Prospero, 1980). Nearby sources of dust, for the North Pacific island-arc and mid-plate volcanos, may contribute proportionally larger grains to the sample site. This sort of disruption by local sources of the generally regular pattern of eolian deposition occurs occasionally (Kennett et al., 1977) and can be detected by examining the sediment mineralogy.

\section{Sediments, samples and analyses}

We have examined the late Cenozoic eolian record in detail at five locations in the North Pacific, three beneath the prevailing westerlies, DSDP Sites 305 and 310 , and a Woods Hole Oceanographic Institution giant piston core LL44-GPC-3, and two beneath the tradewinds, DSDP Sites 292 and 463 (Fig.1, Table I). The DSDP sites are on aseismic rises and recovered nannofossil oozes. Upper Miocene to Recent sediments at Site 305 on the Shatsky Rise and 310 on Hess Rise contain moderate amounts of siliceous microfossils (Larson, Moberly et al., 1975). Siliceous microfossils also occur in Hole 292, but the significant secondary sediment component at that site, on the Benham Rise in the western Philippine Sea, is volcanogenic debris (Karig, Ingle et al., 1975). Donnelly (1975) and Kennett et al. (1977) have shown that Site 292 contains a good record of Cenozoic island-arc volcanism so we added it to our investigation in an attempt to understand the timing and intensity of Pacific volcanism and to anticipate times of volcanic input to our other sites. Carbonate oozes at DSDP Site 463 in the Mid-Pacific Mountains contained no diatoms and only trace amounts of radiolarians (Thiede, Vallier et al., 1981). Core LL44-GPC-3 was raised from abyssal depths beneath the lowproductivity North Pacific gyre and consists of pelagic (red) clay (Corliss and 


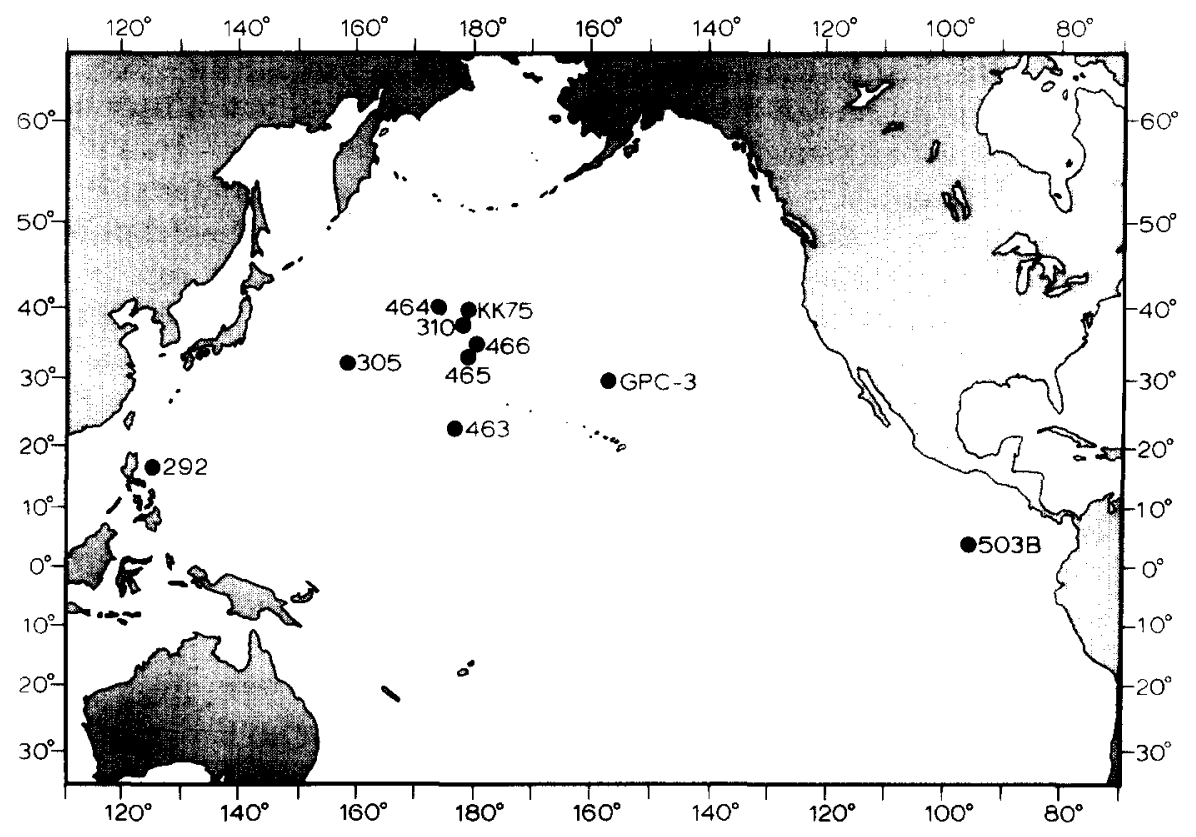

Fig.1. Locations of cores used in the study of eolian sedimentation.

\section{TABLE I}

Location and sediment types of North Pacific core sites

\begin{tabular}{llll}
\hline Site & Location & Depth $(\mathrm{m})$ & Late Cenozoic sediments \\
\hline DSDP 305 & $32^{\circ} 00^{\prime} \mathrm{N}, 157^{\circ} 51^{\prime} \mathrm{E}$ & 2903 & siliceous foraminiferal-nannofossil ooze \\
DSDP 310 & $36^{\circ} 52^{\prime} \mathrm{N}, 176^{\circ} 54^{\prime} \mathrm{E}$ & 3516 & radiolarian-bearing nannofossil ooze \\
LL44-GPC-3 & $30^{\circ} 20^{\prime} \mathrm{N}, 157^{\circ} 49^{\prime} \mathrm{W}$ & 5705 & pelagic clay \\
DSDP 292 & $15^{\circ} 49^{\prime} \mathrm{N}, 124^{\circ} 39^{\prime} \mathrm{E}$ & 2943 & ashy nannofossil ooze \\
DSDP 463 & $21^{\circ} 21^{\prime} \mathrm{N}, 174^{\circ} 40^{\prime} \mathrm{E}$ & 2525 & nannofossil ooze \\
\hline
\end{tabular}

Hollister, 1979). The detrital components in LL44-GPC-3 are eolian in origin and appear to provide a continuous record of Cenozoic atmospheric circulation (Leinen and Heath, 1981).

The stratigraphy used to determine sample ages and sedimentation rates is taken from several sources. For DSDP Sites 305 (Larson, Moberly et al., 1975 ) and 463 (Thiede, Vallier et al.,.1981) we have adopted the zonation used in the Initial Reports of the Deep Sea Drilling Project. The biostratigraphy for Site 292 has been slightly revised from the Initial Reports (Karig, Ingle et al., 1975) by Lohmann and Carlson (1980). Keller $(1978,1979 \mathrm{a}$, $1979 \mathrm{~b}, 1980$ ) has made several revisions to the biostratigraphy of DSDP Site 310 (Larson, Moberly et al., 1975) and we have adopted her sediment ages. For LL44-GPC-3, paleomagnetic inclination data (Prince et al., 1980) were 
used to date sediments younger than $2.45 \mathrm{~m} . \mathrm{y}$. old, and ichthyolith (fish debris) stratigraphy for older sediments (Doyle and Riedel, 1979).

In order to reduce the possibility of sampling non-representative horizons, individual samples from Sites 292,305 and 310 were combined to provide a composite for each million-year interval examined at that site. Whenever possible three or four individual samples were used to create each of the composites (Table II) which were assigned ages corresponding to the midpoint of the age interval sampled. Samples from the other two localities were analyzed individually.

The eolian component is isolated from the freeze-dried samples by treating them successively with acetic acid to remove carbonates, a buffered sodium dithionite-sodium citrate solution to remove oxides, hydroxides and zeolites, and sodium carbonate toremove opal. The residue is freeze dried and weighed to give the weight percent of the eolian component. Authigenic clays and feldspars would survive this extraction procedure but examination of the residue by scanning electron microscopy shows they are at most a minor component and do not introduce a significant error into the MAR and grainsize calculations. A detailed description of the laboratory procedures is given by Rea and Janecek (1981b).

The total sediment mass accumulation rate is the product of the sedimentation rate, assumed to be linear between boundaries of the biostratigaphic zones, and the dry bulk density. Dry bulk density is determined by weight loss upon freeze-drying fresh samples (Site 463 and LL44-GPC-3) or calculated from reported sediment porosity values (Sites 292, 305 and 310 ). MAR of the eolian component is then the product of the total MAR and the weight percent of the eolian components (Table III). The precision of the extraction procedure, based upon analysis of duplicate samples, is $\pm 5 \%$ of the value or better. Accuracy of the resulting eolian MAR values therefore probably depends more on errors resulting from non-linearity of the sedimentation rate than upon our extraction procedure.

Grainsize analysis of the eolian component was carried out on the $6 \phi(16$ microns) to $10 \phi$ ( 1 micron) size fraction at $0.5 \phi$ intervals using a Coulter Counter particle size analyzer. The procedure is described by Graham and Rea (1980); precision of the resulting median grainsize values $\left(\phi_{50}\right.$ of Folk, 1974), based upon differences between duplicate samples, is $\pm 0.05 \phi$.

\section{EOLIAN DEPOSITION IN THE NORTH PACIFIC}

Mineralogy of the carbonate-free fraction of upper Miocene to Quaternary sediments from the five sites show them to be dominated by continentallyderived illite and quartz at Sites 463 (Nagel and Schumann, 1981; Rateev et al., 1981) 305, 310 (Zemmels and Cook, 1975) and LL44-GPC-3 (Leinen and Heath, 1981). At Site 292 in the far West Pacific the dominant mineralogy of the same sediment fraction is smectite and plagioclase, clearly indicating the volcanic provenance of those sediments (Cook et al., 1975).

The total sediment accumulation rates (Table III) in all cores except LL44-GPC-3 are controlled by the input of biogenic materials which 
TABLE II

Composite samples analyzed and individual samples making up the composite

\begin{tabular}{|c|c|c|c|c|}
\hline & $\begin{array}{l}\text { Age of composite } \\
\text { sample (m.y.) }\end{array}$ & $\begin{array}{l}\text { Individual samples, } \\
\text { core-section, interval (cm) }\end{array}$ & $\begin{array}{l}\text { Age of composite } \\
\text { sample (m.y.) }\end{array}$ & $\begin{array}{l}\text { Individual samples, } \\
\text { core-section, interval (cn }\end{array}$ \\
\hline \multirow[t]{10}{*}{ Site 305} & 0.5 & $1.3, \quad 10-12$ & \multicolumn{2}{|c|}{ Site 292 (continued) } \\
\hline & & $\begin{array}{ll}1-4, & 95-97 \\
1-6, & 50-52\end{array}$ & 2.5 & $4-2, \quad 98-100$ \\
\hline & 1.5 & $\begin{array}{l}2-1, \quad 55-57 \\
2-3, \quad 20-22 \\
2-3,145-147\end{array}$ & 3.5 & $\begin{array}{ll}4-4, & 98-100 \\
5-1, & 98-100 \\
5-2, & 98-100\end{array}$ \\
\hline & 2.5 & $3-2,90-92$ & \multirow[t]{3}{*}{4.5} & \multirow{3}{*}{$\begin{array}{rr}5-5, & 98-100 \\
6-1, & 98-100 \\
6-2, & 98-100 \\
6-2, & 102-104\end{array}$} \\
\hline & 3.5 & $4-2, \quad 90-92$ & & \\
\hline & 4.5 & $5 \cdot 1,110-112$ & & \\
\hline & & $\begin{array}{l}5-2,100-102 \\
5-3,100-102 \\
5-4,10-12\end{array}$ & 5.5 & $\begin{array}{ll}6-4, & 98-100 \\
6-5, & 98-100 \\
7-2, & 98-100\end{array}$ \\
\hline & 5.5 & $\begin{array}{l}5-4,145-147 \\
5-5,100-102\end{array}$ & \multirow[t]{2}{*}{6.5} & $\begin{array}{l}7-3,101-103 \\
7-6,106-108\end{array}$ \\
\hline & \multirow[t]{2}{*}{6.5} & \multirow{2}{*}{$\begin{array}{l}6-1,100-102 \\
6-2,140-142 \\
6-3,100-102 \\
6-4,48-50\end{array}$} & & $\begin{array}{l}8-1,95-97 \\
8-4,95-97 \\
8-6,102-104\end{array}$ \\
\hline & & & 10.5 & $9-2, \quad 98-100$ \\
\hline \multirow[t]{18}{*}{ Site 310} & \multirow[t]{2}{*}{0.5} & \multirow{2}{*}{$\begin{array}{l}1-1,115-117 \\
1-3,140-142 \\
2-2,110-112\end{array}$} & 11.5 & $\begin{array}{l}9-4, \quad 98-100 \\
9-6, \quad 98-100\end{array}$ \\
\hline & & & \multirow[t]{2}{*}{12.5} & \multirow{2}{*}{$\begin{array}{l}10-1, \quad 101-103 \\
10-2, \quad 98-100\end{array}$} \\
\hline & \multirow[t]{2}{*}{1.5} & $2-4, \quad 13-15$ & & \\
\hline & & $\begin{array}{ll}2-4, & 60-62 \\
3-2, & 84-86\end{array}$ & \multirow[t]{2}{*}{13.5} & \multirow{2}{*}{$\begin{array}{ll}11-2, & 98-100 \\
11-4, & 98-100 \\
11-6, & 20-22\end{array}$} \\
\hline & \multirow[t]{2}{*}{2.5} & $4-1,110-112$ & & \\
\hline & & $\begin{array}{l}4-4,114-116 \\
4-6,94-96\end{array}$ & \multirow[t]{2}{*}{14.5} & $\begin{array}{l}12-1,118-120 \\
12-2, \quad 98-100\end{array}$ \\
\hline & \multirow[t]{2}{*}{3.5} & $\begin{array}{l}5-6, \quad 60-62 \\
5-6,110-112 \\
6-2,110-112\end{array}$ & & $\begin{array}{ll}12-3, & 30-32 \\
12-4, & 98-100 \\
12-5, & 98-100\end{array}$ \\
\hline & & $6-4,110-112$ & 17.5 & $13-2, \quad 20-22$ \\
\hline & 5.5 & $7-1,125-127$ & & $13-4,98-100$ \\
\hline & & $7-3, \quad 26-28$ & 18.5 & $13-6,100-102$ \\
\hline & & $7-4,94-96$ & 19.5 & $14-1,98-100$ \\
\hline & 6.5 & $\begin{array}{l}8-1,115-117 \\
8-3,110-112\end{array}$ & 21.5 & $\begin{array}{l}14-3,100-102 \\
14-4,98-100 \\
14-6,98-100\end{array}$ \\
\hline & 7.5 & $8-6,125-127$ & & $15-1,98-100$ \\
\hline & & $\begin{array}{l}9-1,110-112 \\
9-2,110-112 \\
9-3,113-115\end{array}$ & 22.5 & $\begin{array}{l}15-2,98-100 \\
15-6,98-100 \\
16-1,98-100\end{array}$ \\
\hline & 8.5 & $\begin{array}{l}9-4,114-116 \\
9-5, \quad 84-86\end{array}$ & & $\begin{array}{l}16-2,98-100 \\
16-5,98-100\end{array}$ \\
\hline & 9.5 & $9-6, \quad 17-18$ & & $16-6,98-100$ \\
\hline & 10.5 & $9-6,115-117$ & 23.5 & $\begin{array}{l}17-2,98-100 \\
17-4,98-100\end{array}$ \\
\hline & 11.5 & $10-2,110-112$ & & $17-6,118-120$ \\
\hline Site 292 & 0.5 & $\begin{array}{l}1-3,10-12 \\
1-4,102-104\end{array}$ & 24.5 & $\begin{array}{ll}18-1, & 98-100 \\
18-3, & 97-99\end{array}$ \\
\hline & 1.5 & $\begin{array}{l}2-3, \quad 50-52 \\
3-1,100-102 \\
3-3, \quad 22-24 \\
3-4, \quad 20-22\end{array}$ & & $\begin{array}{l}18-6, \quad 97-99 \\
19-2,42-44 \\
19-3, \quad 98-100 \\
19-6,118-120 \\
20-2, \quad 57-59\end{array}$ \\
\hline
\end{tabular}


TABLE II (continued)

\begin{tabular}{|c|c|c|c|}
\hline $\begin{array}{l}\text { Age of composite } \\
\text { sample (m.y.) }\end{array}$ & $\begin{array}{l}\text { Individual samples, } \\
\text { core-section, interval (cm) }\end{array}$ & $\begin{array}{l}\text { Age of composite } \\
\text { sample (m.y.) }\end{array}$ & $\begin{array}{l}\text { Individual samples, } \\
\text { core-section, interval }(\mathrm{cm})\end{array}$ \\
\hline \multirow[t]{2}{*}{ Site 292 (continued) } & & \multicolumn{2}{|c|}{ Site 292 (continued) } \\
\hline & $\begin{array}{l}21-2, \quad 45-47 \\
21-4,100-102 \\
22-2,108-110\end{array}$ & $\begin{array}{l}30.5 \\
31.5\end{array}$ & $\begin{array}{l}30-2,100-102 \\
31-2, \quad 77-79\end{array}$ \\
\hline 25.5 & $\begin{array}{ll}23-1, & 78-80 \\
23-2, & 98-100 \\
23-4, & 98-100 \\
24-2, & 98-100\end{array}$ & $\begin{array}{l}32.5 \\
33.5\end{array}$ & $\begin{array}{l}32-1, \quad 102-104 \\
33-1, \quad 80-82 \\
33-2, \quad 53-55 \\
34-1, \quad 50-52 \\
34-2, \quad 100-102\end{array}$ \\
\hline 26.5 & $\begin{array}{l}24-3, \quad 20-22 \\
25-1, \quad 98-100 \\
25-2, \quad 98-100 \\
26-1, \quad 100-102\end{array}$ & $\begin{array}{l}34.5 \\
35.5\end{array}$ & $\begin{array}{l}35-1, \quad 65-67 \\
35-2, \quad 34-36 \\
35-3,100-102\end{array}$ \\
\hline 27.5 & \multirow{4}{*}{$\begin{array}{l}26-2,100-102 \\
27-1,88-90 \\
28 \quad \text { core catcher } \\
29 \quad \text { core catcher }\end{array}$} & 38.5 & $\begin{array}{ll}36-2, & 81-83 \\
36-4, & 50-52\end{array}$ \\
\hline \multirow[t]{3}{*}{29.5} & & 40.5 & $\begin{array}{l}37-1,100^{-}-102 \\
37-2,110-112\end{array}$ \\
\hline & & 41.5 & $37-3,100-102$ \\
\hline & & 44.5 & $38-2,106-108$ \\
\hline
\end{tabular}

commonly are 75 to $95 \%$ of the deposit. At any one site, the interrelationship among the accumulation of carbonate, opaline, eolian and hydrothermalauthigenic materials is complex and, largely for analytical reasons, not fully understood (Leinen and Pisias, 1982). Our data show the late Cenozoic increase in bulk sediment accumulation previously documented for the Pacific Ocean (Worsley and Davies, 1979) and reveal a concomitant increase in eolian deposition. This gross covariance is to be expected in the late Cenozoic as the intensified atmospheric circulation, documented below, should result in more vigorous mixing of surface waters and thus increased biological productivity. Other studies have shown that during periods characterized by unchanging climatic conditions (Thiede and Rea, 1981) or when discrete, closely-spaced samples are analyzed (Rea, 1982) the eolian MAR and total sediment MAR do not covary.

\section{Eolian mass accumulation rates}

The MAR of eolian dust carried by the westerlies has increased significantly since mid-Pliocene time (Fig.2, Table III). At LL44-GPC-3 the increase is from $28 \mathrm{mg} / \mathrm{cm}^{2} / 10^{3} \mathrm{yr} 3.9 \mathrm{~m} . \mathrm{y}$. ago to a maximum of $228 \mathrm{mg} / \mathrm{cm}^{2} / 10^{3} \mathrm{yr}$ $1.4 \mathrm{~m} . \mathrm{y}$. ago; at Site 310 the increase is from 55 to $253 \mathrm{mg} / \mathrm{cm}^{2} / 10^{3} \mathrm{yr}$ between the 3.5 and $0.5-\mathrm{m} . \mathrm{y}$. composite samples. Site 305 shows a much lower increase between 3.5 and $0.5 \mathrm{~m} . \mathrm{y} ., 67-86 \mathrm{mg} / \mathrm{cm}^{2} / 10^{3} \mathrm{yr}$ (Table III, Fig.2). These increases are by factors of $8.1,4.6$ and 1.3 , respectively, an overall average increase in dust accumulation of a factor of 4.7.

In addition to the Quaternary maxima, Sites 310 and 305 also have MAR peaks between 4 and 6 m.y. ago; the peak at 310 on the Hess Rise is much larger than at 305 on the Shatsky Rise (Fig.2). 


\section{TABLE III}

Data from eolian component of North Pacific pelagic sediments. LSR, linear sedimentation rate; DBD, dry bulk density

\begin{tabular}{|c|c|c|c|c|c|c|}
\hline $\begin{array}{l}\text { Age } \\
(\text { m.y.) }\end{array}$ & $\begin{array}{l}\text { LSR } \\
\left(\mathrm{cm} / 10^{3} \mathrm{yr}\right)\end{array}$ & $\begin{array}{l}\text { DBD } \\
\left(\mathrm{g} / \mathrm{cm}^{3}\right)\end{array}$ & $\begin{array}{l}\text { Total MAR } \\
\left(\mathrm{mg} / \mathrm{cm}^{2} / 10^{3} \mathrm{yr}\right)\end{array}$ & $\begin{array}{l}\text { Eolian } \\
\text { fraction } \\
\text { (wt. \%) }\end{array}$ & $\begin{array}{l}\text { Eolian } \\
\text { MAR } \\
\left(\mathrm{mg} / \mathrm{cm}^{2} / 10^{3} \mathrm{yr}\right)\end{array}$ & $\begin{array}{l}\text { Eolian } \\
\text { grainsiz } \\
\left(\phi_{50}\right)\end{array}$ \\
\hline \multicolumn{7}{|c|}{ Site 305} \\
\hline 0.5 & 0.9 & 0.95 & 855 & 10.0 & 86 & 8.25 \\
\hline 1.5 & 0.4 & 1.07 & 428 & 7.6 & 33 & 8.35 \\
\hline 2.5 & 1.1 & 1.08 & 1188 & 6.5 & 77 & 8.72 \\
\hline 3.5 & 1.3 & 1.09 & 1417 & 4.7 & 67 & 8.64 \\
\hline 4.5 & 1.3 & 0.85 & 1105 & 9.2 & 102 & 8.53 \\
\hline 5.5 & 0.5 & 0.96 & 480 & 9.1 & 44 & 8.82 \\
\hline 6.5 & 0.4 & 1.01 & 404 & 8.9 & 36 & 8.51 \\
\hline \multicolumn{7}{|c|}{ Site 310} \\
\hline 0.5 & 1.25 & 0.82 & 1020 & 24.8 & 253 & 8.05 \\
\hline 1.5 & 1.25 & 0.77 & 960 & 17.1 & 164 & 8.16 \\
\hline 2.5 & 1.25 & 0.89 & 1110 & 14.4 & 160 & 8.16 \\
\hline 3.5 & 1.25 & 0.94 & 1180 & 4.7 & 55 & 8.40 \\
\hline 5.5 & 1.20 & 1.10 & 1320 & 22.5 & 297 & 8.22 \\
\hline 6.5 & 0.60 & 1.10 & 660 & 21.1 & 139 & 8.31 \\
\hline 7.5 & 0.15 & 1.13 & 170 & 12.8 & 22 & 8.35 \\
\hline 8.5 & 0.15 & 1.13 & 170 & 9.0 & 15 & 8.35 \\
\hline 9.5 & 0.15 & 0.93 & 140 & 44.8 & 63 & 8.29 \\
\hline 10.5 & 0.20 & 0.95 & 190 & 8.9 & 17 & 8.60 \\
\hline \multicolumn{7}{|l|}{$G P C-3$} \\
\hline 0.30 & 0.243 & 1.307 & 318 & 57.7 & 183 & 8.70 \\
\hline 1.44 & 0.208 & 1.422 & 296 & 77.2 & $228\}$ & 8.65 \\
\hline 1.50 & 0.167 & 1.449 & 242 & 77.8 & $188\}(200)$ & \\
\hline 1.88 & 0.158 & 1.402 & 221 & 77.3 & 171 & 8.64 \\
\hline 1.91 & 0.167 & 1.400 & 233 & 78.0 & $(\mathbf{1 7 9})$ & \\
\hline 1.94 & 0.167 & 1.398 & 233 & 78.8 & 184) & \\
\hline 2.96 & 0.069 & 1.398 & 96 & 73.7 & 71 & 8.72 \\
\hline 3.86 & 0.029 & 1.325 & 38 & 73.6 & 28 & 8.80 \\
\hline 4.62 & 0.032 & 1.340 & 42 & 61.2 & 26 & 8.86 \\
\hline 5.64 & 0.029 & 1.360 & 40 & 66.1 & 26 & 8.79 \\
\hline 6.71 & 0.028 & 1.283 & 36 & 65.8 & 24 & 8.84 \\
\hline 7.79 & 0.028 & 1.363 & 38 & 57.7 & 22 & 8.83 \\
\hline 8.86 & 0.028 & 1.292 & 36 & 62.3 & 22 & 8.92 \\
\hline 9.93 & 0.028 & 1.251 & 35 & 44.2 & 15 & 8.76 \\
\hline 11.36 & 0.028 & 1.274 & 36 & 59.5 & 21 & \\
\hline 12.07 & 0.028 & 1.262 & 36 & 60.9 & 22 & 8.90 \\
\hline \multicolumn{7}{|c|}{ Site 292} \\
\hline 0.5 & 1.00 & 0.58 & 580 & 44.1 & 256 & 8.33 \\
\hline 1.5 & 1.10 & 1.09 & 1200 & 41.9 & 503 & 8.44 \\
\hline 2.5 & 0.70 & 0.97 & 680 & 20.2 & 137 & \\
\hline 3.5 & 1.10 & 1.04 & 1140 & 25.7 & 293 & 8.48 \\
\hline 4.5 & 0.80 & 1.00 & 800 & 22.4 & 179 & 8.55 \\
\hline 5.5 & 1.50 & 1.00 & 1500 & 15.5 & 232 & 8.52 \\
\hline
\end{tabular}


TABLE III (continued)

\begin{tabular}{|c|c|c|c|c|c|c|}
\hline $\begin{array}{l}\text { Age } \\
\text { (m.y.) }\end{array}$ & $\begin{array}{l}\text { LSR } \\
\left(\mathrm{cm} / 10^{3} \mathrm{yr}\right)\end{array}$ & $\begin{array}{l}\text { DBD } \\
\left(\mathrm{g} / \mathrm{cm}^{3}\right)\end{array}$ & $\begin{array}{l}\text { Total MAR } \\
\left(\mathrm{mg} / \mathrm{cm}^{2} / 10^{3} \mathrm{yr}\right)\end{array}$ & $\begin{array}{l}\text { Eolian } \\
\text { fraction } \\
\text { (wt. \%) }\end{array}$ & $\begin{array}{l}\text { Eolian } \\
\text { MAR } \\
\left(\mathrm{mg} / \mathrm{cm}^{2} / 10^{3} \mathrm{yr}\right)\end{array}$ & $\begin{array}{l}\text { Eolian } \\
\text { grainsize } \\
\left(\phi_{50}\right)\end{array}$ \\
\hline \multicolumn{7}{|c|}{ Site 292 continued } \\
\hline 6.5 & 0.45 & 1.07 & 480 & 11.6 & 56 & 8.72 \\
\hline 10.5 & 0.40 & 1.18 & 470 & 14.5 & 68 & \\
\hline 11.5 & 0.40 & 1.10 & 440 & 17.6 & 77 & \\
\hline 12.5 & 0.90 & 1.22 & 1100 & 25.4 & 279 & \\
\hline 13.5 & 0.90 & 1.22 & 1100 & 19.1 & 210 & \\
\hline 14.5 & 0.42 & 1.19 & 500 & 11.9 & 60 & \\
\hline 17.5 & 1.10 & 1.17 & 1290 & 8.0 & 103 & \\
\hline 18.5 & 0.13 & 1.08 & 140 & 15.6 & 22 & \\
\hline 19.5 & 0.13 & 1.08 & 140 & 10.1 & 14 & \\
\hline 21.5 & 1.30 & 1.09 & 1420 & 12.9 & 183 & \\
\hline 22.5 & 1.30 & 0.98 & 1270 & 13.7 & 174 & \\
\hline 23.5 & 1.30 & 1.12 & 1460 & 16.3 & 238 & \\
\hline 24.5 & 6.00 & 1.21 & 7260 & 8.7 & 632 & \\
\hline 25.5 & 4.00 & 1.10 & 4400 & 15.1 & 664 & \\
\hline 26.5 & 1.10 & 1.10 & 1210 & 9.6 & 116 & \\
\hline 27.5 & 1.10 & 1.10 & 1210 & 5.2 & 63 & \\
\hline 28.5 & 1.10 & 1.10 & 1210 & 2.4 & 29 & \\
\hline 29.5 & 1.10 & 1.10 & 1210 & 6.9 & 83 & \\
\hline 30.5 & 1.10 & 1.10 & 1210 & 3.4 & 41 & \\
\hline 31.5 & 1.10 & 1.31 & 1440 & 1.7 & 24 & \\
\hline 32.5 & 1.10 & 1.31 & 1440 & 5.5 & 79 & \\
\hline 33.5 & 1.10 & 1.31 & 1440 & 9.2 & 132 & \\
\hline 34.5 & 0.47 & 1.06 & 500 & 18.9 & 94 & \\
\hline 35.5 & 0.47 & 1.06 & 500 & 10.3 & 52 & \\
\hline 38.5 & 0.47 & 1.06 & 500 & 16.3 & 82 & \\
\hline 40.5 & 0.47 & 1.06 & 500 & 16.5 & 82 & \\
\hline 41.5 & 0.47 & 1.06 & 500 & 4.0 & 20 & \\
\hline 44.5 & 0.47 & 1.06 & 500 & 4.3 & 22 & \\
\hline \multicolumn{7}{|c|}{ Site 463} \\
\hline 0.01 & 0.24 & 1.14 & 274 & 10.2 & 28 & 8.45 \\
\hline 0.73 & 0.21 & 1.07 & 225 & 13.0 & 29 & 8.35 \\
\hline 1.91 & 0.62 & 1.03 & 639 & 8.1 & $52\}$ & $8.58\}$ \\
\hline 2.00 & 0.62 & 1.10 & 682 & 6.2 & $42\}(47)$ & $8.50\}$ \\
\hline 2.33 & 0.75 & 0.95 & 712 & 3.2 & 23 & 8.60 \\
\hline 2.72 & 0.75 & 0.85 & 638 & 3.8 & $24\}$ & 8.56 \\
\hline 2.93 & 0.75 & 1.05 & 788 & 6.2 & $49\}(36)$ & $8.66\}(8.61)$ \\
\hline 3.80 & 0.20 & 1.24 & 248 & 4.3 & 11 & 8.59 \\
\hline 4.04 & 0.28 & 1.10 & 308 & 8.3 & 26 & 8.32 \\
\hline 5.43 & 0.11 & 1.01 & 111 & 3.6 & 4 & 8.59 \\
\hline 6.31 & 0.39 & 1.10 & 429 & 4.1 & 18 & 8.55 \\
\hline 6.83 & 0.39 & 1.10 & 429 & 2.0 & 9 & 8.75 \\
\hline
\end{tabular}




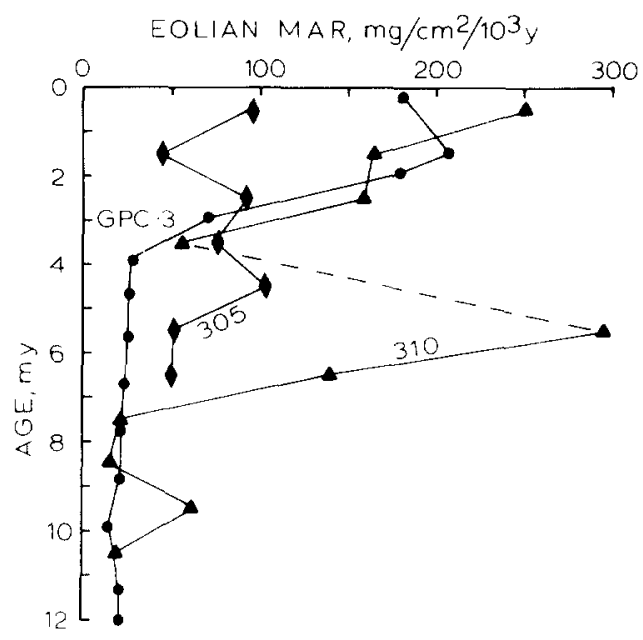

Fig.2. Eolian mass accumulation rate of cores beneath the prevailing westerlies.

There is a latitudinal pattern of accumulation; more northerly sites show greater accumulations of dust during the last 5 m.y. (Fig.3). Our sites are distributed over $10^{\circ}$ of latitude and the eolian MAR increases by approximately a factor of 3 across this distance. This increase reflects both the geographic location of the Asian arid lands between $40^{\circ}$ and $50^{\circ} \mathrm{N}$ and the position of the most intense portion of the westerlies, also $40^{\circ}$ to $50^{\circ} \mathrm{N}$ (Barry and Chorley, 1976). The longitudinal pattern of the MAR values beneath the westerlies is not clear. One might expect Site 305 to have higher MAR values than either 310 or LL44-GPC-3 because it lies closer to the Asian source of dust.

The two tradewind cores exhibit very different MAR histories (Fig.4). Eolian accumulation at Site 292 has been very high, with accumulation rates approaching hemipelagic MAR values of several hundred $\mathrm{mg} / \mathrm{cm}^{2} / 10^{3} \mathrm{yr}$ (Fig.5). Other investigators have estimated the times and amounts of volcanogenic input to the Site 292 sediments (Donnelly, 1975; Kennett et al., 1977) and while our work quantifies that input and better defines its timing, it does not alter the significant conclusions of either study. Drilling at Site 292 penetrated to Eocene basalt. The overlying pelagic sediments contain evidence of four periods of increased volcanogenic input (Fig.5) which are presumed to coincide with periods of intensified volcanic activity in the western Pacific. The oldest and most intense event occurred 23-27 m.y. ago near the time of the Paleogene-Neogene boundary and may be part of a circum-Pacific volcano-tectonic event of that age (Dott, 1969). Distinct events of lesser magnitude occurred 12-14 m.y. ago, 3.5-5.5 m.y. ago, and during the Pleistocene. These events correspond generally in time to periods of volcanic activity previously recognized in plate-margin and mid-plate portions of the Pacific region (Kennett et al., 1977; Rea and Scheidegger, 1979). 


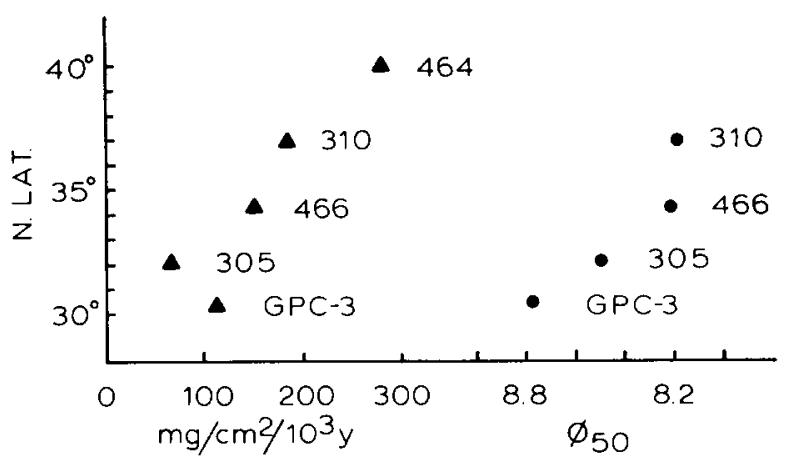

Fig.3. Latitudinal variation of eolian MAR and grainsize. Data for DSDP Cores 464 and 466 from Rea and Harrsch (1981) and our unpublished data.

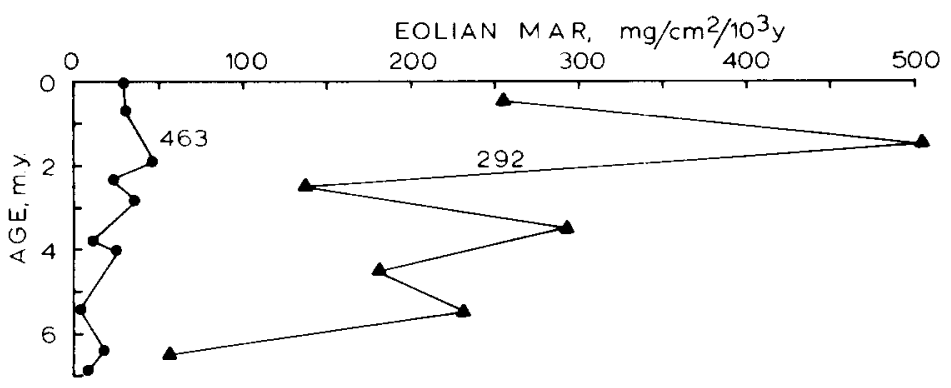

Fig.4. Eolian MAR for cores beneath the northeast tradewinds.

Site 463 appears to record a more realistic history of non-volcanic tradewind transport during the past several million years. MAR values are much lower, by roughly a factor of 5 , than for the westerlies, but the proportional increase in MAR from preglacial to glacial times is the same, a factor of 4.7 (Table III). Similarly derived eolian MAR data exist at one other location in the tradewinds, for the past 450,000 yrs of sediments at DSDP Site 503B in the eastern equatorial Pacific (Fig.1). There eolian MAR values average $64 \mathrm{mg} / \mathrm{cm}^{2} / 10^{3}$ yr over the last five glacial-interglacial cycles (Rea, 1982). At Site 463 , about $10,000 \mathrm{~km}$ downwind, eolian MARs average $38 \mathrm{mg} / \mathrm{cm}^{2}$ / $10^{3} \mathrm{yr}$ over the last $2 \mathrm{~m} . \mathrm{y}$. Low eolian MAR values in the tradewinds appear, from this limited data, to be an ocean-wide phenomenon in the North Pacific and most likely reflect the small size of the continental source areas. Similar differences between eolian deposition rates under the tradewinds and westerlies would not be expected in other oceans (Griffin et al., 1968).

\section{Grainsize of eolian sediments}

The size of the eolian grains, in all cases, increases from late Miocene to Quaternary time (Figs.6 and 7). The change in grainsize can be used to quantify the relative change in wind strength. The calculation is based upon the 


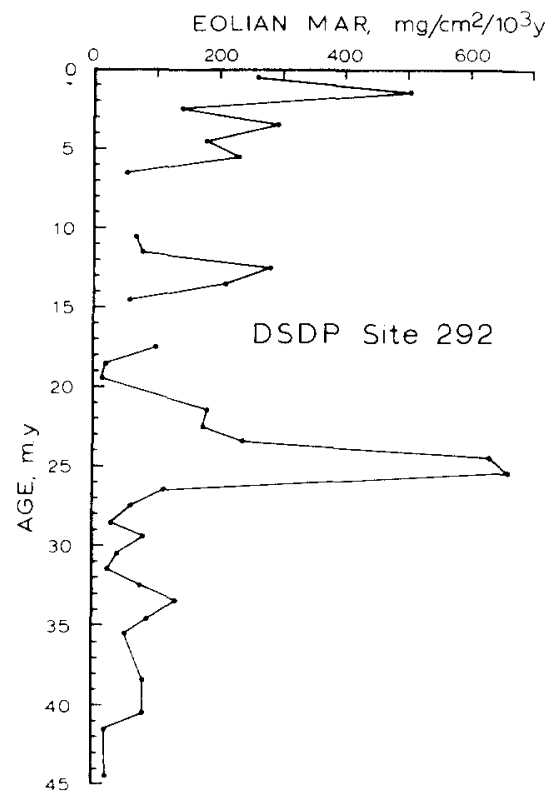

Fig.5. Eocene to Pleistocene eolian MAR of dominantly volcanogenic debris at DSDP Site 292. Gaps in the curve indicate the presence of lacunae.

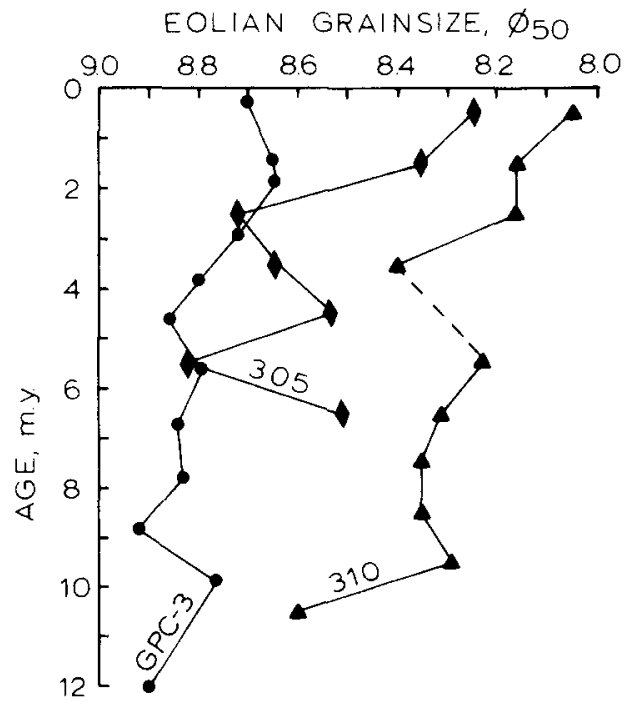

Fig.6. Eolian grainsize for cores beneath the prevailing westerlies. 


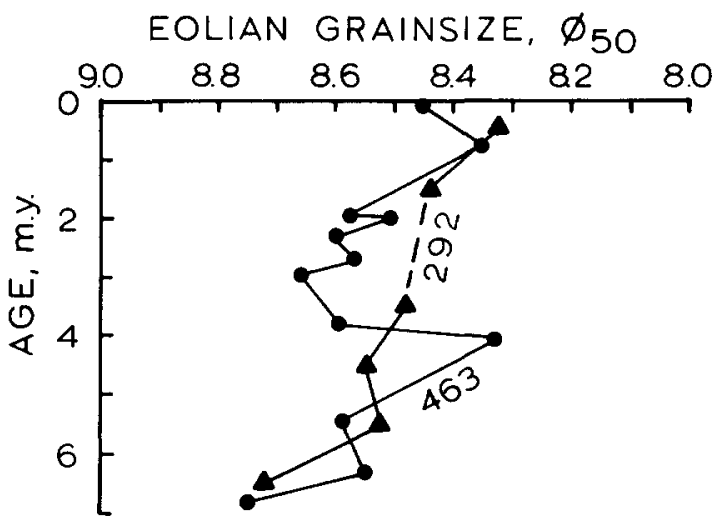

Fig.7. Eolian grainsize for cores beneath the tradewinds.

assumption that, far from their source, eolian grains have a size distribution in equilibrium with average wind intensity (Windom, 1975; Johnson, 1976; Schutz, 1979) such that the settling of the equilibrium grains is balanced by the lifting effect of turbulent atmospheric motions. Changes in wind intensity can then be determined by comparing in ratio form the settling velocities of the different sized particles. In such a ratio the significant terms are the square of the two particle diameters since other terms cancel out. Thus the ratio of high to low wind intensities, $R_{\mathrm{w}}$, is the ratio of the squares of the grainsizes $D_{\mathrm{H}}^{2}$ and $D_{\mathrm{L}}^{2}: R_{\mathrm{w}}=D_{\mathrm{H}}^{2} / D_{\mathrm{L}}^{2}$.

Using this method the increase in intensity of the westerlies from the Pliocene minimum to the Quaternary maximum is by a factor of $1.36,1.92$ and 1.62 at LL44-GPC-3, Sites 305 and 310, respectively. If the same calculation is made comparing the largest Quaternary grains to those present 3.5 m.y. ago, the same ratios are $1.20,1.72$ and 1.62. Our data suggest, therefore, that the northern hemisphere westerlies intensified by a factor of about 1.51 or roughly $50 \%$ with the onset of Northern Hemisphere glaciation in midPliocene time.

Secondary maxima in grainsize occur in conjunction with the secondary MAR maxima at 4.5 m.y. ago in Site 305 and at 5.5 m.y. ago at Site 310 . These early Pliocene maxima imply either somewhat stronger winds then or a local to regional source of larger particles.

The increase in average intensity of the prevailing westerlies from their southern fringe to roughly $45^{\circ} \mathrm{N}$ should be reflected in the grainsize of the eolian sediment. A plot of the average grainsize of the eolian component over the past $5 \mathrm{~m} . \mathrm{y}$. versus latitude reveals this general increase (Fig.3).

The trade wind cores also contain eolian grains that increase in size from the mid-Pliocene to Quaternary (Fig.7). At Site 463 this size increase represents an increase in wind intensity of a factor of 1.54 or 1.45 depending upon whether the minimal value is taken as the low about $3 \mathrm{~m} . \mathrm{y}$. ago or an interpolated value chosen to represent conditions $3.5 \mathrm{~m} . y$. ago. In either case the increase in wind vigor in the tradewinds is the same as that for the 
westerlies, about $50 \%$, for the preglacial to glacial climatic transition. A secondary grainsize maxima about $4 \mathrm{~m}$.y. ago at Site 463 like the lower Pliocene peaks at Sites 305 and 310 may be the result of either regional sources of larger grains or somewhat stronger winds then.

The grain-size curve from Site 292 (Fig.7) reveals only a gently increasing size of eolian grains since $6.5 \mathrm{~m} . \mathrm{y}$. ago. In light of the large volcanogenic contribution to Site 292 sediments, we hesitate to discuss the grainsize data from that core in terms of changes in zonal wind intensity.

\section{LATE CENOZOIC ATMOSPHERIC CIRCULATION}

\section{Paleoclimate}

Changes in climate which alter the vigor of the zonal winds are those which affect the pole-to equator temperature gradient. During the Cenozoic, these changes have, for the most part, been associated with cooling of the polar regions. Cenozoic polar cooling apparently occurred in three steps, rather than in a generally continuous fashion. Some early Cenozoic cooling may have preceded the first major reduction in temperature of the Antarctic region which occurred about $38 \mathrm{~m} . \mathrm{y}$. ago at the Eocene-Oligocene boundary and was responsible for initiating production of cold bottom waters (Savin et al., 1975; Savin, 1977; Kennett, 1977). A large ice cap first developed in Antarctica between about 14.8 and $13 \mathrm{~m} . \mathrm{y}$. ago (Savin, 1977; Kennett, 1977; Woodruff et al., 1981). Another episode of significant polar cooling occurred with the formation of Northern Hemisphere ice cover, an event apparently triggered by the final emergence of the Isthmus of Panama between 3.6 and 3.2 m.y. ago (Savin, 1977; Kennett, 1977; Schnitker, 1980; Prell, Gardner et al., 1980).

Global climate has also become drier since the Early Cenozoic with increasing aridity through the Neogene (Dorf, 1964; Wolfe and Hopkins, 1967; Kemp, 1978; Wolfe, 1978; Frakes, 1979). The world overall apparently was more arid during the last glacial maximum 18,000 yrs ago than during the present interglacial although that generalization does not hold for all regions (Sarnthein, 1978; Peterson et al., 1979; Rea, 1982).

\section{North Pacific record}

The North Pacific record of eolian deposition permits quantification of the increased intensity of the zonal winds that accompanied the formation of northern hemisphere ice cover. The increase in eolian grainsize began about 3 or $3.5 \mathrm{~m} . y$. ago; a more detailed sampling program would be necessary to further define this timing. Since that time the wind systems have become more intense by a factor of 1.5 , this $50 \%$ increase appears to be the same for both the westerlies and the tradewinds.

The supply of eolian dust to the ocean increased by a factor of 4.5 since $3.5 \mathrm{~m} . \mathrm{y}$. ago. As the several mineralogical analyses of this material reported 
above show a dominance of illite and quartz in the eolian fraction, the large late Pliocene increases in eolian MAR evidently records a greater supply of dust from increasingly arid continents, rather than from the Quaternary increase in circum-Pacific volcanic activity (Kennett et al., 1977). Our data suggest a significant increase in the aridity of the low and mid-latitude regions of the Northern Hemisphere that essentially coincided with the growth of Northern Hemisphere ice sheets. Long term data from core LL44-GPC-3 show this late Cenozoic increase in eolian deposition rate to be several times larger than any prior change during the past 70 m.y. (Janecek et al., 1980; Leinen and Heath, 1981).

The maxima in eolian MAR and grainsize that occur between about 4 and 6 m.y. ago apparently do not correspond to any significant changes in global temperature gradients. The single simplest explanation is that these data record the latest Miocene to early Pliocene volcanic episode that occurred along the Pacific and Philippine Sea island arcs (Kennett and Thunnell, 1975; Kennett et al., 1977) and in mid-plate settings along the Emperor Seamounts (Jackson, Koisumi et al., 1980; Mann and Muller, 1980) and the Hawaiian Ridge (Rea and Scheidegger, 1979). Locations nearest the volcanos, Sites 292 and 310 have the largest lower Pliocene MAR values, GPC-3 and Site 463 , farthest away, show almost no change. Volcanic glass and pumice occur in lower Pliocene sediments at Site 310 (Larson, Moberley et al., 1975); inorganic materials at Site 292 are dominantly volcanogenic (Cook et al., 1975; Donnelly, 1975).

\section{SUMMARY}

The late Cenozoic history of eolian deposition in the North Pacific records climatological and volcanic events since late Miocene time. A pulse of volcanic activity centered about $5 \mathrm{~m}$.y. ago provided locally significant amounts of wind-blown volcanic debris to the North Pacific. The rather sudden deterioration of Northern Hemisphere climate beginning 3-3.5 m.y. ago occasioned the growth of ice sheets and an increase in the pole-to equator temperature gradient. Both the prevailing westerlies and the northeast tradewinds increased in intensity by about $50 \%$ in response to the polar cooling. Global aridity increased markedly at the same time as these other changes. The mass flux of dust from continents to oceans increased by a factor of approximately 4.5 in both wind systems, although the westerlies transport about 5 times as much dust, from Asian deserts, as do the tradewinds.

\section{ACKNOWLEDGEMENTS}

This report represents some of the results of a joint project between the Universities of Michigan and Rhode Island. Margaret Leinen and Nick Pisias at URI provided composite samples, initially from the Deep Sea Drilling Project, and the samples from LL44-GPC-3. They also provided helpful comments and suggestions throughout the course of the investigation and on 
this manuscript. We also thank the two anonymous journal reviewers for their constructive criticism.

The work was supported by the National Science Foundation, Grant OCE 78-25341.

\section{REFERENCES}

Barry, G.R. and Chorley, R.J., 1976. Atmosphere, Weather and Climate (3rd ed.). Methuen, London, $432 \mathrm{pp}$.

Berger, W.H., 1976. Biogenous deep sea sediments: Production, preservation and interpretation. In: J.P. Riley and R. Chester (Editors), Chemical Oceanography, Volume 5. Academic Press, New York, N.Y., pp.265-388.

Bishop, J.K.B., Edmond, J.M., Ketten, D.R., Bacon, M.P. and Silker, W.B., 1977. The chemistry, biology, and vertical flux of particulate matter from the upper $400 \mathrm{~m}$ of the equatorial Atlantic Ocean. Deep-Sea Res., 24: 511-548.

Bishop, J.K.B., Ketten, D.R. and Edmond, J.M., 1978. The chemistry, biology and vertical flux of particulate matter from the upper $400 \mathrm{~m}$ of the Cape Basin in the southeast Atlantic Ocean. Deep-Sea Res., 25: 1121-1161.

CLIMAP, 1976. The surface of the ice-age earth. Science, 191: 1311-1317.

Cook, H.E., Zemmels, I. and Matti, C.J., 1975. X-ray mineralogy data, far western Pacific, Leg 31 Deep Sea Drilling Project. In: D.E. Karig, J.C. Ingle, Jr. et al., Initial Reports of the Deep Sea Drilling Project, Vol. 31. U.S. Govt. Printing Office, Washington, D.C., pp.883-895.

Corliss, B.H. and Hollister, C.D., 1979. Cenozoic sedimentation in the central North Pacific. Nature, 282: 707-709.

Delany, A.C., Parkin, D.W., Griffin, J.J., Goldberg, E.D. and Reimann, B.E.F., 1967. Airborne dust collected at Barbados. Geochim. Cosmochim. Acta, 31: 885-909.

Donnelly, T.W., 1975. Neogene explosive volcanic activity of the western Pacific: Sites 292 and 296, DSDP Leg 31. In: D.E. Karig, J.C. Ingle, Jr. et al., Initial Reports of the Deep Sea Drilling Project, Vol. 31. U.S. Govt. Printing Office, Washington, D.C., pp.577-597.

Dorf, E., 1964. The use of fossil plants in palaeoclimatic interpretations. In: A.E.M. Nairn (Editor), Problems in Palaeoclimatology. Wiley-Interscience, London, pp.13-30.

Dott Jr., R.H., 1969. Circum-Pacific late Cenozoic structural rejuvenation: Implications for sea-floor spreading. Science, 166: 874-876.

Doyle, P. and Riedel, W.R., 1979. Cretaceous to Neogene ichthyoliths in a giant piston core from the Central North Pacific. Micropalaeontology, 25: 337-364.

Ferguson, W.S., Griffin, J.J. and Goldberg, E.D., 1970. Atmospheric dusts from the North Pacific - a short note on long-range eolian transport. J. Geophys. Res., 75: 1137-1139.

Folk, R.L., 1974. Petrology of Sedimentary Rocks. Hemphill, Austin, Texas, $182 \mathrm{pp}$.

Frakes, L.A., 1979. Climates Through Geologic Time. Elsevier, New York, N.Y., 310 pp.

Gates, W.L., 1976. Modelling the ice age climate. Science, 191: 1138-1144.

Glaccum, R.A. and Prospero, J.M., 1980. Saharan aerosols over the tropical North Atlantic - Mineralogy. Mar. Geol., 37: 295-321.

Graham, E.J. and Rea, D.K., 1980. Grainsize and mineralogy of sediment cores from western Lake Huron. J. Great Lakes Res., 6: 129-140.

Griffin, J.J., Windom, H. and Goldberg, E.D., 1968. The distribution of clay minerals in the World Ocean. Deep-Sea Res., 15: 433-459.

Heath, G.R., 1979. Simulations of a glacial paleoclimate by three different atmospheric general circulation models. Palaeogeogr. Palaeoclimatol. Palaeoecol., 26: 291-303.

Honjo, S., 1980. Material fluxes and modes of sedimentation in the mesopelagic and bathypelagic zones. J. Mar. Res., 38: 53-97.

Honjo, S. and Roman, M.R., 1978. Marine copepod fecal pellets: Production, preservation and sedimentation. J. Mar. Res., 36: 45-57. 
Jackson, E.D., Koisumi, I. et al., 1980. Initial Reports of the Deep Sea Drilling Project, Vol. 55. U.S. Govt. Printing Office, Washington, D.C., 868 pp.

Janecek, T.R., Rea, D.K., Pisias, N.G. and Leinen, M., 1980. Cenozoic eolian input to the Northeastern Pacific Ocean, data from core LL-44-GPC-3. Geol. Soc. Am., Abstr. with Programs, 12, p.455.

Johnson, L.R., 1976. Particle-size fractionation of eolian dusts during transport and sampling. Mar. Geol., 21: M17-M21.

Johnson, L.R., 1979. Mineralogical dispersal patterns of North Atlantic deep-sea sediments with particular reference to eolian dusts. Mar. Geol., 29: 335-345.

Karig, D.E., Ingle Jr., J.C. et al., 1975. Initial Reports of the Deep-Sea Drilling Project, Vol. 31. U.S. Govt. Printing Office, Washington, D.C., 927 pp.

Keller, G., 1978. Late Neogene biostratigraphy and paleoceanography of DSDP Site 310 Central North Pacific and correlation with the southwest Pacific. Mar. Micropalaeontol., 3: $97-119$.

Keller, G., 1979a. Late Neogene paleoceanography of the North Pacific DSDP Sites 173, 310, and 296. Mar. Micropalaeontol., 4: 159-172.

Keller, G., 1979b. Early Pliocene to Pleistocene planktonic foraminiferal datum levels in the North Pacific: DSDP Sites 173, 310, 296. Mar. Micropalaeontol., 4: 281-294.

Keller, G., 1980. Middle to late Miocene planktonic foraminiferal datum levels and paleoceanography of the north and southeastern Pacific Ocean. Mar. Micropalaeontol., 5: 249-281.

Kemp, E.M., 1978. Tertiary climatic evolution and vegetation history in the Southeast Indian Ocean region. Palaeogeogr., Palaeoclimatol., Palaeoecol., 24: 169-208.

Kennett, J.P., 1977. Cenozoic evolution of Antarctic glaciation, the circum-Antarctic Ocean, and their impact on global paleoceanography. J. Geophys. Res., 82: 38433860 .

Kennett, J.P. and Thunnell, R.C., 1975. Global increase in Quaternary explosive volcanism. Science, 187: 497-503.

Kennett, J.P., McBirney, A.R. and Thunnell, R.C., 1977. Episodes of Cenozoic volcanism in the circum.Pacific region. J. Volcanol. Geotherm. Res., 2: 145-163.

Larson, R.L., Moberly, R. et al., 1975. Initial Reports of the Deep Sea Drilling Project, Vol. 32. U.S. Govt. Printing Office, Washington, D.C., 980 pp.

Leinen, M. and Heath, G.R., 1981. Sedimentary indicators of atmospheric activity in the Northern hemisphere during the Cenozoic. Palaeogeogr. Palaeoclimatol., Palaeoecol., $36: 1-21$.

Leinen, M. and Pisias, N., 1982. An objective technique for determining end-member compositions and for partitioning sediments according to their sources. Geochim. Cosmochim. Acta, in press.

Lisitzin, A.P., 1972. Sedimentation in the Worlds Oceans. Soc. Econ. Palaeontol. Mineral., Spec. Publ. 17, Tulsa, 218 pp.

Lohmann, G.P. and Carlson, J.J., 1980. Oceanographic Significance of Pacific Late Miocene Calcareous Nannoplankton. Woods Hole Oceanogr. Inst., Tech. Rept. 78.

Manabe, S. and Hahn, D.C., 1977. Simulation of the tropical climate of the ice age. J. Geophys. Res., 82: 3889-3912.

Mann, U. and Muller, G., 1980. Mineralogy of the sedimentary sections encountered on Leg 55 (Sites 430 through 433 ), based on X-ray diffractometry. In: E.D. Jackson, I. Koisumi et al., Initial Reports of the Deep Sea Drilling Project, Vol. 55. U.S. Govt. Printing Office, Washington, D.C., pp.857-859.

Moore Jr., T.C., Burckle, L.H., Geitzenauer, K., Luz, B., Molina-Cruz, A., Robertson, J.H., Sachs, H., Sancetta, C., Thiede, J., Thompson, P. and Wenkam, C., 1980. The reconstruction of sea-surface temperatures in the Pacific Ocean of 18,000 B.P. Mar. Micropalaeontol., 5: 215-247.

Nagel, U. and Schumann, D., 1981. X-ray mineralogy of sediments, Deep Sea Drilling Project Leg 62. In: J. Thiede, T.L. Vallier et al., Initial Reports of the Deep Sea Drilling Project, Vol. 62. U.S. Govt. Printing Office, Washington, D.C., pp.529-535. 
Parkin, D.W., 1974. Trade winds during the glacial cycles. Proc. R. Soc. London, Ser. A, 337: 73-100.

Parkin, D.W. and Padgham, R.C., 1975. Further studies on trade winds during the glacial cycles. Proc. R. Soc. London, Ser. A, 346: 245-260.

Peterson, G.M., Webb III, T., Kutzbach, J.E., van der Hammen, T., Wijmstra, T.A. and Street, F.A., 1979. The continental record of environmental conditions at $18,000 \mathrm{yr}$ B.P.: An initial evaluation. Quat. Res., 12: 47-82.

Prell, W.L., Gardner, J.V., Adelseck, C , Blechschmidt, G., Fleet, A.J., Keigwin jr., L.D., Kent, D., Ledbetter, M.T., Mann, U., Mayes, L., Reidel, W.R., Sancetta, C., Spariosu, D. and Zimmerman, H.B., 1980. Hydraulic piston coring of late Neogene and Quaternary sections in the Caribbean and equatorial Pacific: Preliminary results of Deep Sea Drilling Project Leg 68. Geol. Soc. Am. Bull., Part I, 91: 433-444.

Prince, R.A., Heath, G.R. and Kominz, M., 1980. Paleomagnetic studies of central North Pacific sediment cores: Stratigraphy, sedimentation rates and the origin of magnetic instability. Geol. Soc. Am. Bull., Part 2, 91: 1789-1835.

Prospero, J.M. and Bonatti, E., 1969. Continental dust in the atmosphere of the eastern Equatorial Pacific. J. Geophys. Res., 74: 3362-3371.

Prospero, J.M., Glaccum, R.A. and Nees, R.T., 1981. Atmospheric transport of soil dust from Africa to South America, Nature, 289: 570-572.

Rateev, M.A., Timofeev, P.P. and Koporulin, V.I., 1981. Clay minerals in Mesozoic and Cenozoic sediments of Deep Sea Drilling Project Leg 62. In: J. Thiede, T.L. Vallier et al., Initial Reports of the Deep Sea Drilling Project, Vol. 62. U.S. Govt. Printing Office, Washington, D.C., pp.537-544.

Rea, D.K., 1982. Fluctuation in eolian sedimentation during the past five glacial-interglacial cycles: A preliminary examination of data from DSDP Site 503B, eastern equatorial Pacific Ocean. In: J.V. Gardner, W.L. Prell et al., Initial Reports of the Deep Sea Drilling Project, Vol. 68. U.S. Govt. Printing Office, Washington, D.C., in press.

Rea, D.K. and Harrsch, E.C., 1981. Mass accumulation rates of the non-authigenic, inorganic, crystalline (eolian) component of deep-sea sediments from the Hess Rise, DSDP Sites 464, 465 and 466. In: J. Thiede, T.L. Vallier et al., Initial Reports of the Deep Sea Drilling Project, Vol. 62. U.S. Govt. Printing Office, Washington, D.C., pp.661-668.

Rea, D.K. and Janecek, T.R., 1981a. Late Cretaceous history of eolian deposition in the Mid-Pacific Mountains, central North Pacific Ocean. Palaeogeogr., Palaeoclimatol., Palaeoecol., 36: 55-67.

Rea, D.K. and Janecek, T.R., 1981b. Mass accumulation rates of the non-authigenic, inorganic, crystalline (eolian) component deep-sea sediments from the western MidPacific mountains, DSDP Site 463. In: J. Thiede, T.L. Vallier et al., Initial Reports of the Deep Sea Drilling Project, Vol. 62. U.S. Govt. Printing Office, Washington, D.C., pp.653-659.

Rea, D.K. and Scheidegger, K.F., 1979. Eastern Pacific spreading rate fluctuation and its relation to Pacific area volcanic episodes. J. Volcanol. Geotherm. Res., 5: 135-148.

Rex, R.W. and Goldberg, E.D., 1958. Quartz contents of Pelagic sediments of the Pacific Ocean. Tellus, 10: 153-159.

Sarnthein, M., 1978. Sand deserts during glacial maximum and climatic optimum. Nature, 272: $43-46$.

Savin, S.M., 1977. The history of the earth's surface temperature over the past 100 million years. Annu. Rev. Earth Planet. Sci., 5: 319-355.

Savin, S.M., Douglas, R.G. and Stehli, F.G., 1975. Tertiary marine paleotemperatures. Geol. Soc. Am. Bull., 86: 1499-1510.

Scheidegger, K.F. and Krissek, L.A., 1982. Dispersal and deposition of eolian and fluvial sediments off Peru and northern Chile. Geol. Soc. Am. Bull., 93: 150-162.

Schnitker, D., 1980. Global paleoceanography and its deep water linkage to the Antarctic glaciation. Earth Sci. Rev., 16-20. 
Schütz, L., 1979. Sahara dust transport over the North Atlantic Ocean - Model calculations and measurements. In: C. Morales (Editor), Saharan Dust Mobilization, Trans- port, Deposition. Wiley, New York, N.Y., pp.267-277.

Thiede, J. and Rea, D.K., 1981. Mass-accumulation rates of Barremian to Recent biogenic sediments from the Mid-Pacific Mountains (Deep Sea Drilling Project Site 463) and Hess Rise (Sites 464, 465, and 466), central North Pacific Ocean. In: J. Thiede, T.L. Vallier et al., Initial Reports of the Deep Sea Drilling Project, Vol. 62. U.S. Govt. Printing Office, Washington, D.C., pp.637-651.

Thiede, J., Vallier, T.L. et al., 1981. Initial Reports of the Deep Sea Drilling Project, Vol. 62. U.S. Govt. Printing Office, Washington, D.C., 1120 pp.

Van Andel, Tj.H., Heath, G.R. and Moore Jr., T.C., 1975. Cenozoic History and Paleoceanography of the Central Equatorial Pacific. Geol. Soc. Am. Mem., 143, Geol. Soc. Am., Boulder, Colo., 134 pp.

Windom, H.L., 1969. Atmospheric dust records in permanent snowfields: Implications to marine sedimentation. Geol. Soc. Am. Bull., 80: 761-782.

Windom, H.L., 1975. Eolian contributions to marine sediments. J. Sediment. Petrol., 45: 520-529.

Windom, H.L., 1976. Lithogenous material in marine sediments. In: J.P. Riley and R. Chester (Editors), Chemical Oceanography, Vol. 5. Academic Press, New York, N.Y., pp.103-135.

Windom, H.L. and Chamberlain, C.F., 1978. Dust-storm transport of sediments to the North Atlantic Ocean. J. Sediment. Petrol., 48: 385-388.

Wolfe, J.A., 1978. A paleobotanical interpretation of Tertiary climates in the northern hemisphere. Am. Sci., 66: 694-703.

Wolfe, J.A. and Hopkins, D.M., 1967. Climatic changes recorded by Tertiary land floras in northwestern North America. In: K. Hatai (Editor), Tertiary Correlations and Climatic Changes in the Pacific. 11th Pacific Sci. Congress, Tokyo, Symp., 25: 67-76.

Woodruff, F., Savin, S.M. and Douglas, R.G., 1981. Miocene stable isotope record: A detailed deep Pacific Ocean study and its paleoclimatic implications. Science, 212 : 665-668.

Worsley, T.R. and Davies, T.A., 1979. Cenozoic sedimentation in the Pacific Ocean: Steps toward a quantitative evaluation. J. Sediment. Petrol., 49: 1131-1146.

Zemmels, I. and Cook, H.E., 1975. X-ray mineralogy data from the northwest Pacific, Leg 32, Deep Sea Drilling Project. In: R.L. Larson, R. Moberly et al., Initial Reports of the Deep Sea Drilling Project, Vol. 32. U.S. Govt. Printing Office, Washington, D.C., pp.547-557. 